\title{
Changes of Photosynthesis-Related Parameters and Productivity of Spring Oilseed Rape under Different Nitrogen and Sulphur Fertilizers Supply
}

\author{
Zane Mintāle ${ }^{1}$, Māra Vikmane ${ }^{2}$ \\ 1 - Latvian Plant Protection Research Centre Ltd, Struktoru iela 14a, Riga, \\ 2 - Department of Plant Physiology, Faculty of Biology, University of Latvia, Kronvalda Bulv. 4, Riga
}

\begin{abstract}
Fertilization with essential mineral elements is important to get high quality yield results. The lack of necessary mineral elements in soil can affect oilseed rape plant physiological functions, photosynthesis and plant productivity. Oilseed rape plants have high requirements for nitrogen and as oil crop - for sulphur. The aim of the investigation was to explain changes of chlorophyll $a$ fluorescence parameters in spring oilseed rape leaves and yield changes under nitrogen and sulphur supply. During laboratory experiments changes of chlorophyll $a$ fluorescence parameters and during field experiments changes of yield parameters under different nitrogen and sulphur supply were observed. Laboratory and field experiments showed that sulphur fertilizer rate $18 \mathrm{~kg} \mathrm{ha}^{-1}$ is the most effective sulphur dose for spring oilseed rape, when nitrogen $55 \mathrm{~kg} \mathrm{ha}^{-1}$ is added, because its presence has positive effect on photosynthetic reactions. There was found out in laboratory experiments that chlorophyll $a$ fluorescence parameters $F_{v} / F_{m}$ and $P I$ can be used to describe sulphur and nitrogen mineral element supply efficacy on spring oilseed rape. There was observed in the field experiment that oilseed rape yield increases significantly (from $+0.34 \mathrm{t} \mathrm{ha}^{-1}$ to $+0.64 \mathrm{t}$ $\left.h^{-1}\right)$ under optimal $\left(S_{18} N_{55}\right)$ nutrient supply, but lack of sulphur leads to significant yield losses. To avoid excessive fertilizer usage, its negative impact on plant physiology and yield losses, we consider that sulphur: nitrogen $=1: 3$ as additional fertilizer is optimal for spring oilseed rape plants.
\end{abstract}

Keywords - Brassica napus, chlorophyll, fluorescence, nitrogen and sulphur top-dressing, yield.

\section{INTRODUCTION}

Oilseed rape (Brassica napus L.) is one of the most important sources of vegetable oil in the world and widely grown as main oil crop in Europe [1] - [4]. The total area of oilseed rape grown in Latvia has increased almost 7 times during the past 10 years (2002: 18.4 thousand ha; 2011: 121.3 thousand ha) (data from Central Statistical Bureau of Latvia). Oilseed rape growers in Latvia usually prefer winter oilseed rape varieties, but due to different weather conditions across Latvia in some regions, especially Eastern Latvia, it is possible to grow only spring oilseed rape [5]. The area of spring oilseed rape was $63.6 \%$ of the total oilseed rape area in Latvia in 2011 (data from Central Statistical Bureau of Latvia). Compared to other European countries the average spring oilseed rape yields in Latvia are relatively low.

Request for high seed yield increased rapidly, accordingly with increasing number of opportunities for use of oilseed rape. Fertilization with essential mineral elements is important to gain high quality yield. New oilseed rape varieties can produce high seed yields, but it is important to ensure proper growing conditions, including complex and balanced mineral fertilisation during growing season. Oilseed rape requires a higher amount of nutrients as compared to cereals [6], [7]. Nitrogen is limiting element for plant growth, because it is an integral component not only of chlorophyll but also of amino acids, proteins, nucleotides, chromosomes, genes, ribosomes and is also a constituent of all enzymes [7], [8]. Sulphur is also an important mineral element for oilseed rape development [9], [10]. Several studies have established positive interaction between sulphur and nitrogen [11] - [13]. Sulphur fertilizer improves nitrogen use efficiency [12] and is involved in the synthesis of chlorophyll and it is in the sulphurcontaining amino acid [14] and enzyme content [15]. The deficiency of necessary mineral elements as well as too high element amounts in soil has negative impact on oilseed rape physiological functions, photosynthesis and plant productivity [16].

Rapeseed contains $40-46 \%$ of oil [2], [6], [15], [17] and $43-48 \%$ of protein [2]. Oil content of seeds can be affected by many factors, such as variety, crop management and fertilisation [2]. Several research confirmed essential role of mineral fertilizers on rapeseed oil quality [2], [7], [11], [18] - [20].

Chlorophyll content and photosynthetic activity in plant leaves are main parameters describing plant physiological conditions [21], [22] and mineral nutrition of plants [23] - [25]. Young plant leaves which have reached optimum size and development stage are the best indicators for mineral nutrient content in oilseed rape plants, especially for deficiency of elements [26]. Non-destructive methods 


\section{Mintāle Z., Vikmane M. CHANGES OF PHOTOSYNTHESIS-RELATED PARAMETERS AND PRODUCTIVITY OF SPRING OILSEED RAPE UNDER DIFFERENT NITROGEN AND SULPHUR FERTILIZERS SUPPLY}

of plant analysis have become more popular in plant biology [22], [27]. Chlorophyll $a$ fluorescence has been widely used to measure the stress level of plants induced by many factors [21], [28] - [30].

However, there is a lack of information about the effect of supplementary sulphur and nitrogen on physiological processes in plants, such as photosynthesis as a yield forming factor under Latvian climatic and agroecological conditions. Therefore, the aim of the research was to explain changes of chlorophyll $a$ fluorescence parameters in spring oilseed rape leaves and yield changes under nitrogen and sulphur supply.

\section{MATERIALS AND METHODS}

\section{Laboratory experiments}

Laboratory experiments were carried out at University of Latvia, Faculty of Biology in 2011.

Spring oilseed rape variety 'Forte' was used in studies under laboratory conditions. Seeds were sown on January 19 in plastic containers (five seeds per container), filled with mineral-enriched peat substrate KANO $\left(\mathrm{pH}_{\mathrm{KCl}} 5.5-7.0\right.$, nitrogen content $180 \mathrm{mg} \mathrm{L}^{-1}$, $\mathrm{K}_{2} \mathrm{O}$ content $400 \mathrm{mg} \mathrm{L}^{-1}, \mathrm{P}_{2} \mathrm{O}_{5}$ content $245 \mathrm{mg} \mathrm{L}^{-1}$ ). Containers were placed in a growth chamber, at $15 \mathrm{~h}$ photoperiod, $22 \pm 2{ }^{\circ} \mathrm{C}$ and illuminated with luminescent lamps with photon flux density of 200 $\mu \mathrm{mol} \mathrm{m} \mathrm{m}^{-2}$.

Five different trial treatments were included in the study: 1) untreated - $\mathrm{S}_{0} \mathrm{~N}_{0}$, 2) $\mathrm{S}_{18} \mathrm{~N}_{15}$, 3) $\left.\mathrm{S}_{18} \mathrm{~N}_{55}, 4\right)$ $\mathrm{S}_{36} \mathrm{~N}_{55}$, and 5) $\mathrm{S}_{0} \mathrm{~N}_{55}$ (Table 1). Ammonium sulphate $\left(\left(\mathrm{NH}_{4}\right)_{2} \mathrm{SO}_{4}\right.$; nitrogen content $21 \%$, sulphur content $24 \%$ ) was used as a sulphur (S) fertilizer source in the experiments at rates 18 and $36 \mathrm{~kg} \mathrm{ha}^{-1}$. Ammonium nitrate $\left(\mathrm{NH}_{4} \mathrm{NO}_{3}\right.$; nitrogen content $\left.34.4 \%\right)$ was used as an additional nitrogen (N) fertilizer source in experiments. Treatment $5\left(\mathrm{~S}_{0} \mathrm{~N}_{55}\right)$ with nitrogen rate $55 \mathrm{~kg} \mathrm{ha}^{-1}$ was included in experiment to observe pure nitrogen effect on the physiological processes in spring oilseed rape plants.

Fertilizer treatment was performed on February 10 when plants had reached $3-4$ leaf stage. For fertilisation a $10 \%\left(\mathrm{NH}_{4}\right)_{2} \mathrm{SO}_{4}$ and $\mathrm{NH}_{4} \mathrm{NO}_{3}$ solutions in distilled water were used. Each experimental pot received $50 \mathrm{~mL}$ of mineral fertilizer solutions at calculated dose-rates and $50 \mathrm{~mL}$ of distilled water were applied on the untreated pots.

Measurement of chlorophyll $a$ fluorescence was performed four times: on February 24 (14 days after fertilizer were applied - DAF), on March 3 (21 DAF), on March 10 (28 DAF) and on March 17 (35 DAF). Chlorophyll $a$ fluorescence was measured using a Handy PEA (Plant Efficiency Analyzer) portable fluorescence measurement system (Hansatech Instruments, UK).

Young plant leaves were chosen for analysis. Dark adaptation was performed with special leaf clips for $25 \mathrm{~min}$ before measurement. Twenty measurements per treatment were performed. The data were analyzed by appropriate software.

TABLE 1

SCHEME OF EXPERIMENT

\begin{tabular}{llll}
\hline Treatments & $\begin{array}{c}\text { Top-dressing } \\
\text { rate, } \mathrm{kg} \mathrm{ha}^{-1}\end{array}$ & $\begin{array}{l}\text { Top-dressing } \\
\text { rate per 1 pot, } \\
\mathrm{mL}\end{array}$ & $\begin{array}{l}\text { Top-dressing } \\
\text { rate per 1 plot } \\
\left(30 \mathrm{~m}^{2}\right), \mathrm{g}\end{array}$ \\
\hline $\begin{array}{l}\text { 1. Untreated } \\
\text { 2. } \mathrm{S}_{18} \mathrm{~N}_{15}\end{array}$ & - & - \\
{$\left[\left(\mathrm{NH}_{4}\right)_{2} \mathrm{SO}_{4}\right]$} & 75.0 & 0.75 & 225.0 \\
$\begin{array}{l}3 . \mathrm{S}_{18} \mathrm{~N}_{55} \\
{\left[\left(\mathrm{NH}_{4}\right)_{2} \mathrm{SO}_{4}\right]}\end{array}$ & $75.0+116.0$ & $0.75+1.16$ & $225.0+348.0$ \\
$+\left[\mathrm{NH}_{4} \mathrm{NO}_{3}\right]$ & & & \\
$4 . \mathrm{S}_{36} \mathrm{~N}_{55}$ & & & \\
{$\left[\left(\mathrm{NH}_{4}\right)_{2} \mathrm{SO}_{4}\right]$} & $150.0+67.0$ & $1.50+0.67$ & $450.0+201.0$ \\
$+\left[\mathrm{NH}_{4} \mathrm{NO}_{3}\right]$ & & & \\
$5 . \mathrm{S}_{0} \mathrm{~N}_{55}$ & 160.0 & 1.60 & 480.0 \\
{$\left[\mathrm{NH}_{4} \mathrm{NO}_{3}\right]$} & & & \\
\hline
\end{tabular}

\section{Field experiments}

Field trials were established in Priekuli municipality in 2010 and in Talsi municipality in 2011 on the farmer's field in spring oilseed rape. In the field trials the treatments were arranged within a randomized complete block design with four replicates. Plot size was $30 \mathrm{~m}^{2}$. In both years conventional soil tillage was employed according to recommendations for spring oilseed rape. Plant protection products were applied to the whole trial as necessary.

In 2010 the soil type was sod podzolic loamy sand and in the field had $\mathrm{pH}_{\mathrm{KCl}} 5.3$, an organic content of $46 \mathrm{~g} \mathrm{~kg}^{-1}$ and a previous crop was annual ryegrass and clover mix. Spring oilseed rape variety 'Forte' was seeded on April 30 at seeding rate $4.5 \mathrm{~kg} \mathrm{ha}^{-1}$. At sowing the trial area was fertilized with mineral fertilizer $\left(\mathrm{N}_{4}: \mathrm{P}_{15}: \mathrm{K}_{31}\right) 250 \mathrm{~kg} \mathrm{ha}^{-1}$.

In 2011 the soil type was sod-podzolic loam and in the field had $\mathrm{pH}_{\mathrm{KCl}} 5.5$, an organic content of $26 \mathrm{~g} \mathrm{~kg}^{-1}$ and a previous crop was spring barley. Spring oilseed rape variety 'Perfekt' was seeded on May 5 at seeding rate $5.0 \mathrm{~kg} \mathrm{ha}^{-1}$. Before sowing the trial area was fertilized with mineral fertilizer $\left(\mathrm{N}_{16}: \mathrm{P}_{16} \mathrm{~K}_{16}\right) 330 \mathrm{~kg}$ ha $^{-1}$.

Field trial treatments were the same, used in laboratory experiments. Sulphur and nitrogen topdressings according to trial scheme (Table 1) were broadcasted on the field on June 19 (in 2010) and on June 8 (in 2011).

The total seed yield from each plot was harvested by trial combine "Sampo 130" on August 17 (in 2010) and "Wintersteiger Delta" on September 6 (in 2011). Yield was recalculated to $\mathrm{t} \mathrm{ha}^{-1}$ and given at $100 \%$ purity and $8 \%$ moisture content. 


\section{FERTILIZERS SUPPLY}

Data on meteorological conditions were obtained from Priekuli (in 2010) and Stende (in 2011) HMS. The growing season in 2010 was unusually warm and air temperatures exceeded long-term norm during the season: $0.3-5.3^{\circ} \mathrm{C}$ above the norm. Overall amount of precipitation per month was satisfactory and favourable for spring oilseed rape development during the beginning of growing season, but was only $51.6 \%$ of norm during the period of seed development in July. The weather during the growing season in 2011 continued to be warmer than long term averages $(0.3-$ $2.9^{\circ} \mathrm{C}$ above the norm). During the beginning of the growing season (April, May) amount of precipitation was only $67.9-74.2 \%$ of norm. There was sufficient amount of precipitation during June, July and August to provide very good conditions for reproductive organ formation and seed development of spring oilseed rape.

The oil content (\%) of spring oilseed rape seeds was determined in Latvia University of Agriculture Institute of Agrobiotehnology, Grain and Seed Research Laboratory using Grain Analyzer INFRATEC 1241 (FOSS Analytical, Sweden) using a special device for oil content determination.

Data analysis was performed using MS Excel and the statistical package GenStat for Windows $15^{\text {th }}$ edition.

\section{RESULTS AND DISCUSSION}

\section{Laboratory experiments}

Chlorophyll $a$ fluorescence parameters $\mathrm{F}_{\mathrm{v}} / \mathrm{F}_{\mathrm{m}}$ and PI were used to describe additional sulphur and nitrogen fertilizer effect on photosynthesis of spring oilseed rape plants.

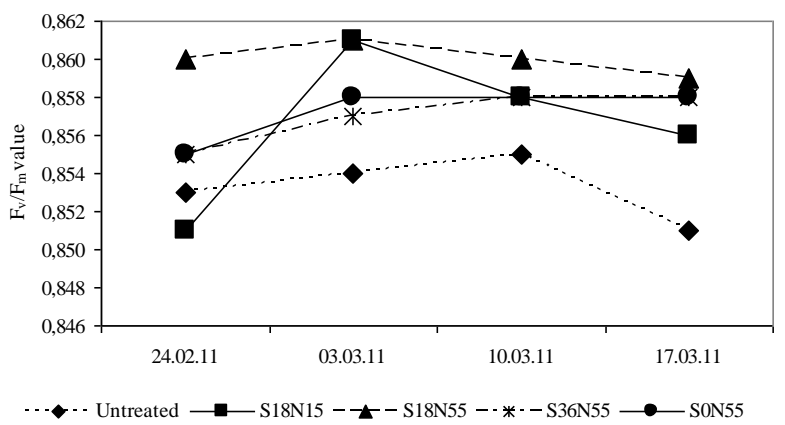

Fig. 1. Effect of sulphur and nitrogen fertilizer on $F_{v} / F_{m}$ of spring oilseed rape plants under laboratory conditions

Parameter $\mathrm{F}_{\mathrm{v}} / \mathrm{F}_{\mathrm{m}}$ is widely used to detect plant stress and is directly correlated to the photochemical efficiency of the photosystem II for which values of 0.83 correspond to high efficiency [31]. In our experiment $\mathrm{F}_{\mathrm{v}} / \mathrm{F}_{\mathrm{m}}$ values exceeded 0.83 in all treatments (Fig. 1). The highest $\mathrm{F}_{\mathrm{v}} / \mathrm{F}_{\mathrm{m}}$ values during whole time of experiment were detected to the plants with optimum sulphur and nitrogen fertilizer supply $\left(\mathrm{S}_{18} \mathrm{~N}_{55}\right)$. It indicates that fertilizer at the optimum rates has positive effect on light dependent reactions of photosynthesis. Lower $F_{v} / F_{m}$ values were detected to the $\mathrm{S}_{36} \mathrm{~N}_{55}$ and $\mathrm{S}_{0} \mathrm{~N}_{55}$ plants, compared to $\mathrm{S}_{18} \mathrm{~N}_{15}$ and $\mathrm{S}_{18} \mathrm{~N}_{55}$ plants. In comparison with all treatments, untreated plants had very low photosynthetic activity. Results indicate that mineral element deficiency $\left(\mathrm{S}_{0} \mathrm{~N}_{55}\right)$ or too high rates $\left(\mathrm{S}_{36} \mathrm{~N}_{55}\right)$ can lead to decrease of photosynthetic efficiency. The results of present study agree with those of Verhoeven and his coworkers [32] who reported that $F_{v} / F_{m}$ value in spinach plants decreases under conditions of nitrogen deficiency.

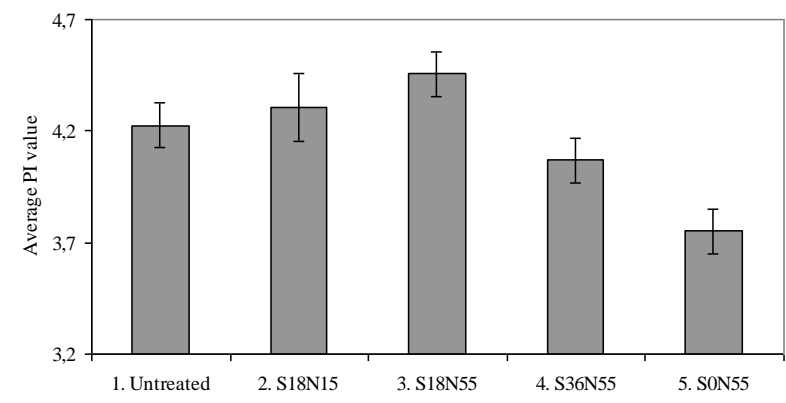

Fig. 2. Effect of sulphur and nitrogen fertilizer on PI of spring oilseed rape plants under laboratory conditions

The Performance Index (PI) is suggested to be one of the most valuable fluorescence parameters describing vitality of the plant [33]. Additional sulphur and nitrogen fertilizer at optimum rate $\left(\mathrm{S}_{18} \mathrm{~N}_{55}\right)$ significantly increased spring oilseed rape plant vitality (Fig. 2). Sulphur deficiency $\left(\mathrm{S}_{0} \mathrm{~N}_{55}\right)$ as well as sulphur double dose $\left(\mathrm{S}_{36} \mathrm{~N}_{55}\right)$ had led to significant plant vitality decrease compared to control plants and plants fertilized with $18 \mathrm{~kg}$ sulphur hawhich only approves significant role of sulphur and nitrogen ratio in plant growth [12].

\section{Field experiments}

Yield of spring oilseed rape varied between experimental years in spite of the fact that both spring oilseed rape varieties used in experiment were highly productive.

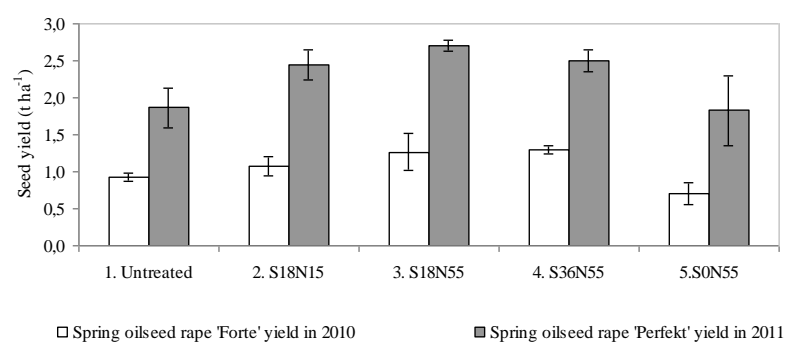

Fig. 3. The effect of sulphur and nitrogen fertilizer on spring oilseed rape seed yield

The average spring oilseed rape yield (Fig. 3) in the control plots was very low $\left(0.9-1.9 \mathrm{t} \mathrm{ha}^{-1}\right)$, especially in 2010, when oilseed rape seed development was strongly affected by meteorological conditions. Researchers in Iran concluded that seed yield decreases can be associated with the water stress during rapeseed reproductive growth stages [34]. Seed yield increased with an increase of sulphur fertilizer 


\section{Mintāle Z., Vikmane M. CHANGES OF PHOTOSYNTHESIS-RELATED PARAMETERS AND PRODUCTIVITY OF SPRING OILSEED RAPE UNDER DIFFERENT NITROGEN AND SULPHUR FERTILIZERS SUPPLY}

rate from 0 to $36 \mathrm{~kg} \mathrm{ha}^{-1}$. In both years significantly higher spring oilseed rape seed yield was produced in the plots where sulphur 18 and $36 \mathrm{~kg} \mathrm{ha}^{-1}$ and nitrogen $55 \mathrm{~kg} \mathrm{ha}{ }^{-1}$ fertilizer was applied compared to untreated. It is obvious that there is a relationship between nitrogen and sulphur rates and their impact on seed yield. A significant impact of increasing sulphur fertilizer rates on the oilseed rape seed yield was recorded in earlier studies [10], [12].

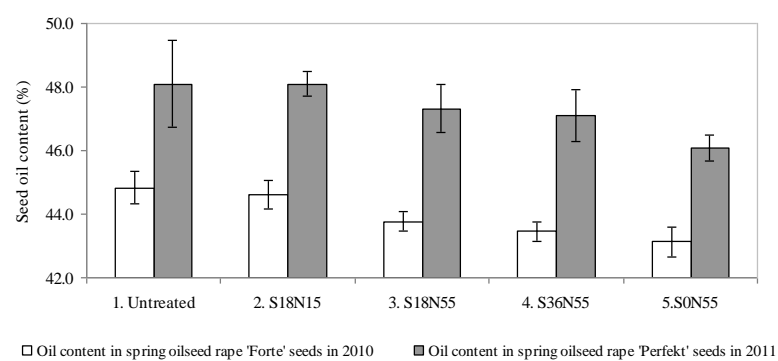

Fig. 4. The effect of sulphur and nitrogen fertilizer on the oil content in spring oilseed rape seeds

One of the most important quality factors of oilseed rape is oil content. The average oil content in the spring oilseed rape 'Forte' seeds was $43-45 \%$ and in spring oilseed rape 'Perfekt' seeds: $43-48 \%$ (Fig. 4). Oil content was highest in the untreated plot oilseed rape plant seeds and decreased with the increasing sulphur and nitrogen fertilizer rates. Negative correlation between oil content and nitrogen fertilizer rate has been reported previously [7], [15], [17]. It is strongly related with protein content in oilseed rape seeds, which increases with the increasing nitrogen rate [7] and has negative impact on oil content in seeds [1].

\section{CONCLUSIONS}

Chlorophyll $a$ fluorescence parameters $\mathrm{F}_{\mathrm{v}} / \mathrm{F}_{\mathrm{m}}$ and PI can be used to describe sulphur and nitrogen mineral element supply efficacy on spring oilseed rape to predict possible yield results.

High seed yields of good quality can be expected when an optimum concentration and good balance of additional sulphur and nitrogen are used. Sulphur and nitrogen fertilization in relation $1: 3$ should be considered not only as a fertilizer increasing biological spring oilseed rape yield, but improving the quality of plant product and reducing the unnecessary distribution of fertilizer in the environment.

\section{$\mathrm{V}$ REFERENCES}

[1] K. Orlovius, "Fertilizing for high yield and quality oilseed rape," IPI Bulletin No. 16, International Potash Institute, Switzerland. 125 pp., 2003.

[2] P. Lääniste, J. Jõudu, V. Eremeev, "Oil content of spring oilseed rape seeds according to fertilisation," Agronomy Research, Vol. 2, No 1, pp. 83-86, 2004.

[3] R. Snowdon, W. Lühs, W. Friedt, "Oilseed rape," in Genome mapping and molacular breeding in plants, Vol. 2. C. Kole Ed., Springer, pp. 55-84, 2007.
[4] M. Hristova-Cherbadzi and G. Georgiev, "Breeding and agrotechnics of rape (Brassica napus L.). Winter rape distribution, cultivation and investigation in Bulgaria," Agricultural Science and Technology, Vol. 2, No 4, pp. 174 $182,2010$.

[5] A. Oḷukalns un E. Ruža, "Vasaras rapsis," Rīga, Eḷ̦as augu audzētāju un pārstrādātāju asociācija „Latvijas Rapsis,” 2003.

[6] G. W. Rathke, O. Christen, W. Diepenbrock, "Effects of nitrogen source and rate on productivity and quality of winter oilseed rape (Brassica napus L.) grown in different crop rotations," Field Crops Research, Vol. 94, pp. 103-113, 2005.

[7] L. Narits, "Effect of nitrogen rate and application time to yield and quality of winter oilseed rape (Brassica napus L. var. Oleifera subvar. Biennis)," Agronomy Research, Vol.8, Special Issue III, pp. 671-686, 2010.

[8] N. A. Anjum, S. S. Gill, S. Umar, I. Ahmad, A. C. Duarte, E. Pereira, "Improving growth and productivity of oleiferous brassicas under changing environment: significance of nitrogen and sulphur nutrition, and underlying mechanisms," The Scientific World Journal, Vol. 2012, 2012.

[9] F. J. Zhao, E. J. Evans, P. E. Bilsborrow, J. K. Syers, "Sulphur uptake and distribution in double and single low varieties of oilseed rape (Brassica napus L.)," Plants and Soil, Vol. 150, pp. 69-76, 1993.

[10] M. Abdallah, P. Etienne, A. Ourry, F. Meuriot, "Do initial S reserves and mineral $\mathrm{S}$ availability alter leaf $\mathrm{S}-\mathrm{N}$ mobilization and leaf senescence in oilseed rape? " Plant Science, Vol. 180, pp. 511-520, 2011.

[11] S. P. McGrath and F. J. Zhao, "Sulphur uptake, yield responses and the interactions between nitrogen and sulphur in winter oilseed rape (Brassica napus)," Journal of Agricultural Science, Vol. 126, pp. 53-62, 1996.

[12] J. Fishmes, P. C. Vong, A. Guckert, E. Frossard, "Influence of sulphur on apparent N-use Efficiency, yield and quality of oilseed rape (Brassica napus L.) grown on calcareous soil," European Journal of Agronomy, Vol. 12, pp. 127-141, 2000.

[13] J. Potarzycki, "Winter oilseed rape nitrogen fertilization efficiency as induced by sulphur application," in Chemistry and biochemistry in the agricultural production, environment production, human and animal health, H. Górecki, Z. Dobrzański, P. Kafarski Ed. Czech-Pol-Trade, Praque, Brussels, pp. 322-327, 2006.

[14] G. Šiaudinis, "The effect of nitrogen and sulphur fertilisation on the elemntal composition and seed quality of spring oilseed rape," Zemdirbyste-Agriculture, Vol. 97, No 4, pp. 47-56, 2010.

[15] A. Ruža, A. Adamovičs, B. Bankina, A. Bērzin̦š, J. Driksis, A. Kārkliņš, Dz. Kreišmane, Dz. Kreita, I. Turka, E. Ruža, Augkopība, Jelgava, Latvijas Lauksaimniecības Universitāte, 2004.

[16] L. Hřivna, R. Richter, T. Lošák, J. Hlušek, "Effect of increasing doses of nitrogen and sulphur on chemical composition of plants, yields and seed quality in winter rape," Rolstlinná Výroba, Vol. 48, No 1, pp. 1-6, 2002.

[17] E. Mäeorg, P. Lääniste, J. Jõudu, U. Mäeorg, "The oil content and sterol composition of spring oilseed rape seeds," Agronomijas Vēstis (Latvian Journal of Agronomy), Vol. 8, pp. 133-136, 2005.

[18] B. Butkute, G. Šidlauskas, A. Mašauskienè, L. Sliesaravičienè, "The effect of agronomic factors and growth conditions on protein and fat content in the seed of spring oilseed rape (Brassica napus L.) and on the variation of fatty acids," Zemdirbyste-Agriculture, Vol. 70, pp. 160-175, 2000.

[19] B. Butkutè, A. Masauskiene, L. Sliesaraviciene, "Impact of different agronomic factors on the seed quality of spring oilseed rape cv. Star," Scientific Papers of the Agricultural University of Crakow - Kracow, Vol. 77, No 375, pp. 165177, 2001.

[20] G. Ahmad, A. Jan, M. Arif, M. T. Jan, R. A. Khattak, "Influence of nitrogen and sulphur fertilization on quality of canola (Brassica napus L.) under rainfed conditions," Journal of Zhejiang University Science, Vol. 8, No 10, pp. 731-737, 2007.

[21] В. Ф. Гаврииленко, Т. В Жигалова, "Большой практикум по фотосинтезу," Москва, Академия, 2003.

[22] H. S. Neufield, A. H. Chappelka, G. L. Somers, K. O. Burkey, A. W. Davison, P. L. Finkelstein, "Visible foliar injury caused 
Mintāle Z., Vikmane M. CHANGES OF PHOTOSYNTHESIS-RELATED PARAMETERS AND PRODUCTIVITY OF SPRING OILSEED RAPE UNDER DIFFERENT NITROGEN AND SULPHUR FERTILIZERS SUPPLY

by ozone alters the relationships between SPAD meter readings and chlorophyll concentrations in cutlea coneflower," Photosynthesis Research, Vol. 87, pp. 281-286, 2006.

[23] G. E. Varvel, J. S. Schepers, D. D. Francis, "Ability for inseason correction of nitrogen deficiency in corn using chlorophyll meters," Soil Science Society of America Journal, Vol. 61, pp. 1233-1239, 1997.

[24] H. Marschner, "Mineral nutrition of higher plants," Second edition, London, Academic Press, 1999.

[25] J. Zhang, A. M. Blackmer, J. W. Ellsworth, K. J. Koehler, "Sensitivity of chlorophyll meters for diagnosing nitrogen def ciencies of corn in production agriculture," Agronomy Journal, Vol. 100, No 3, pp. 543-550, 2008.

[26] C. Colnenne, M. J. Meynard, R. Reau, E. Justes, A. Merrien, "Determination of a critical nitrogen dilution curve for winter oilseed rape," Annals of Botany, Vol. 81, pp. 311-317, 1998

[27] K. Oxborough, "Imaging of chlorophyll a fluorescence: theoretical and practical aspects of an emerging technique for the monitoring of photosynthetic performance," Journal of Experimental Botany, Vol. 55, pp. 1195-1205, 2004.

[28] A. S. Verhoeven, B. Demmig-Adams, W. E. Adams, "Enhanced employment of the xantophyll cycle and thermal energy dissipation in spinach exposed to high light and $\mathrm{N}$ stress," Plant Physiology, Vol. 113, pp. 817-824, 1997.
[29] I. Samsone, U. Andersone, M. Vikmane, B. Ievina, G. Pakarna, G. Ievinsh, "Nondestructive mothods in plant biology: an accurate measurement of chlorophyll content by a chlorophyll meter," Acta Universitatis Latviensis, Vol. 723, pp. 145-154, 2007.

[30] F. F. Cassana, A. R. Falqueto, E. J. B. Braga, J. A. Peters, M. A. Bacarin, "Chlorophyll a fluorescence of sweet potato plants cultivated in vitro during ex vitro acclimatization," Brazilian Journal of Plant Physiology, Vol. 22, No 3, pp. 167-170, 2010.

[31] K. Maxwell, G. N. Johnson, "Chlorophyll fluorescence - a practical guide," Journal of Experimental Botany, Vol. 51, pp. 659-668, 2000.

[32] A.S. Verhoeven, B. Demmig-Adams, W.E. Adams, "Enhanced employment of the xantophyll cycle and thermal energy dissipation in spinach exposed to high light and $\mathrm{N}$ stress," Plant Physiology, Vol. 113, pp. 817-824, 1997.

[33] A. Pinior,G. Grunewaldt-Stöcker, H. Alten, R. J. Strasser, "Mycorrhizal impact on drought stress tolerance of rose plants probed by chlorophyll a fluorescence, proline content and visual scoring," Mycorrhiza, Vol. 15, pp. 596-605, 2005.

[34] M. Ahmadi, "Effect of zinc and nitrogen fertilizer rates on yield and yield componentsof oilseed rape (Brassica napus L.)," American Eurasian Journal of Agricultural \& Environmental Science, Vol. 7, pp. 259-264, 2010. 